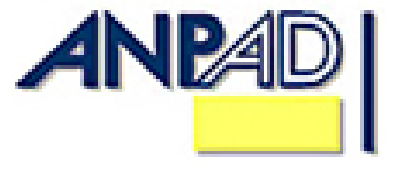

Disponível em

http://www.anpad.org.br/rac

RAC, Curitiba, v. 15, n. 6, art. 3,

pp. 1016-1039, Nov./Dez. 2011

$(\mathrm{cc})$ EY-No

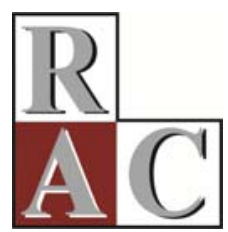

\title{
Um "Pas de Deux" da Estratégia com a Arte: as Práticas do Grupo Corpo de Balé
}

\section{A 'Pas de Deux' of Strategy with Art: the Practices of the Corpo de Balé Ballet Group}

Ernani Viana Saraiva *

E-mail: ernanisaraiva@gmail.com Universidade Federal de Minas Gerais - UFMG Belo Horizonte, MG, Brasil.

Alexandre de Pádua Carrieri E-mail: alexandre@cepead.face.ufmg.br Universidade Federal de Minas Gerais - UFMG Belo Horizonte, MG, Brasil.

Ana Rosa Camillo Aguiar E-mail: aguiar.paduacarrieri@terra.com.br Belo Horizonte, MG, Brasil.

Valéria da Glória Pereira Brito E-mail: vgpbrito@gmail.com Universidade Federal de Lavras - UFLA Lavras, MG, Brasil.

* Endereço: Ernani Viana Saraiva

Rua Helena Mesquita, 60, Bairro Nova Suissa, Belo Horizonte/MG, 30421-115.

Copyright (C) 2011 RAC. Todos os direitos, até mesmo de tradução, são reservados. É permitido citar parte de artigos sem autorização prévia, desde que seja identificada a fonte. 


\title{
Resumo
}

Este trabalho volta-se a apreender as estratégias organizacionais do Grupo Corpo, companhia de balé, com sede em Belo Horizonte, Minas Gerais. Partiu-se da premissa de que as estratégias estão configuradas nas práticas cotidianas de gestão da organização. A fim de atender ao objetivo proposto, utilizaram-se, como perguntas orientadoras, questões que são consideradas recursivas nesse campo: (a) Que é estratégia? (b) Quem é o estrategista? (c) Que fazem os estrategistas? (d) Que é que pode explicar uma análise dos estrategistas e suas ações? Como suporte metodológico à consecução do objetivo da pesquisa, foi realizada uma etnografia. Combinado a esta, adotou-se o procedimento de Grounded Theory, para desenvolver a proposta de conceituar estratégia de forma substantiva. Foi também realizada a análise situacional (Clarke, 2005). No final do trabalho, foi observada a construção de três mundos organizacionais identificados no Grupo Corpo: o mundo do Grupo de Balé, o mundo do Corpo Cidadão e o mundo da Escola de Dança. Foram também identificadas as práticas e as relações construídas entre estas e os sujeitos que efetivamente as implantam na organização estudada. Assim, foi montado um esquema relacional entre as práticas encontradas e os atores individuais e coletivos. Com base na análise do esquema relacional foi construído um conceito de estratégia para o Grupo Corpo.

Palavras-chave: estratégia; Grupo Corpo; práticas.

\begin{abstract}
This work aims to understand the organizational strategies used by the ballet company Grupo Corpo, based in Belo Horizonte, Minas Gerais, Brazil. It is based upon the premise that such practices are configured (in) this organization's daily management practices. In order to achieve the proposed objective, four questions considered to be recursive in this field were used as guidelines: (a) What is strategy? (b) Who is the strategist? (c) What do strategists do? (d) What can explain an analysis of strategists and their actions? As methodological support, an ethnography was conducted. In addition, the Grounded Theory procedure was used to develop the proposal of bringing about a substantial concept of strategy. A situational analysis was also done (Clarke, 2005) and at the end of the study, three organizational spheres within the Corpo de Balé group: its Ballet Group sphere, its Citizen sphere, and its Dance School sphere. The practices and relationships constructed between these and the subjects that actually included them in the organization under study were also identified. Thus, a relational scheme was established, involving the observed practices and the individual and collective actors. Based on the analysis of the relational scheme a strategy concept was elaborated for the Corpo de Balé group.
\end{abstract}

Key words: strategy; Corpo de Balé Group; practices. 


\section{Introdução}

O objetivo deste trabalho é construir um conceito de estratégia, a partir da observação das práticas na organização Grupo Corpo de Balé. Buscou-se identificar as práticas desenvolvidas pelos seus membros e desenvolver uma explicação do que seria estratégia para eles. Entende-se por práticas o conceito proposto por Reckwitz (2002), respaldado por Jarzabkowski, Balogun e Seidl (2007); este diz que elas são ações que se institucionalizam de alguma maneira, incorporando formas de pensar e falar, de usar coisas, de compreender e saber, bem como de sentir e de se posicionar. A fim de atender ao objetivo proposto, utilizaram-se, como perguntas orientadoras, questões que são consideradas recursivas nesse campo: (a) Que é estratégia? (b) Quem é o estrategista? (c) Que fazem os estrategistas? (d) Que é que pode explicar uma análise dos estrategistas e suas ações?

O tema estratégia é recorrente nos estudos de administração; haja vista o discurso existente no meio empresarial e acadêmico que reforça sua importância. A despeito da massificação de seu conceito e do espaço hegemônico que ocupa na administração, pode-se encontrar na literatura abordagens mais críticas, que buscam refletir sobre a ortodoxia dominante. Este artigo tenta afastar-se da abordagem clássica e predominante de pensar estratégia com seu foco determinista, linear, em que as estratégias de uma organização são delineadas pelos estrategistas como único caminho a ser percorrido. Optamos por uma abordagem interpretativa, sendo a estratégia apreendida como atividade socialmente realizada, construída pelas práticas, ações, interações e negociações de múltiplos atores (Jarzabkowski, 2005).

Para entender melhor as práticas e a estratégia, Johnson, Melin e Whittington (2003, p. 14) sugerem que examinemos de perto a forma como é constituído o trabalho nos sistemas e processos organizacionais. Neste sentido, empiricamente escolheu-se, para responder às questões acima referenciadas, a organização Grupo Corpo, companhia de balet fundada em 1975, com sede em Belo Horizonte, Minas Gerais. Possui extenso repertório, reconhecimento nacional e internacional; sua história é pontuada por continuados sucessos de público, alguns incluídos na história das artes cênicas brasileiras como marcos.

Como suporte metodológico à consecução do objetivo da pesquisa, foi realizada uma etnografia, tida como a melhor forma de observar as práticas em uma organização e compreender os significados delas para os atores envolvidos (Balogun, Huff, \& Johnson, 2003, Jarzabkowski \& Wilson, 2002; Samra-Fredericks, 2000, 2003; Whittington, 2002a). Combinado à etnografia, adotou-se o procedimento de Grounded Theory, para desenvolver a proposta de conceituar estratégia de forma substantiva. Foi também realizada a análise situacional (Clarke, 2005), uma vertente da Grounded Theory, desenvolvida com base nos pressupostos construtivistas de Charmaz (2000, 2005). Julgou-se a adoção dos esquemas situacionais, relacionais, de mundos sociais e arenas, além dos esquemas posicionais (Clarke, 2005); enfim, uma maneira mais extensa e, portanto, mais completa de possibilitar a compreensão não só da situação sob investigação, como também de todos os elementos contextuais e condicionantes do fenômeno investigado.

Como técnicas de suporte à investigação etnográfica para a coleta de dados e para a análise situcional, usou-se a pesquisa documental, a observação participante e entrevistas semi-estruturadas. Dessa investigação resultou um registro feito diários de campo, gravações de depoimentos espontâneos e entrevistas formais, vídeos e fotografias. A construção de entendimento desse registro foi baseada na Análise de Conteúdo, mais precisamente uma análise temática, ou seja, núcleos de sentido componentes de comunicações - escritas e orais - que tenham algum sentido para o objeto analítico visado (Minayo, Deslandes, Cruz-Neto, \& Gomes, 1996) e na Análise do Discurso para a construção dos percursos semânticos, na análise dos intra e interdiscursos (Charaudeau \& Maingueneau, 2004).

O presente artigo divide-se em cinco partes, além desta introdução. Assim, a segunda parte refere-se à delimitação teórica do tema proposto; na seguinte buscou-se apresentar os caminhos metodológicos escolhidos para se construir um conceito de estratégia. Na quarta parte apresenta-se a 
análise dos esquemas situacionais, expostos como mundos (arenas), onde estão configuradas as práticas observadas. A quinta parte representa o esforço de, a partir das práticas, responder ao que foi proposto na pesquisa, ou seja, o que é estratégia, no âmbito do grupo Corpo. Finalmente, na última parte, tecemos considerações sobre o estudo realizado, em que se apontam os acertos e limitações da pesquisa.

\section{Estratégia como Prática}

Os estudos de estratégia em organizações começaram a tomar fôlego a partir da década de 60 . Inicialmente, seu foco maior eram as ideias de criação de modelos gerenciais, instrumentais para a alta gerência, pautados nos objetivos econômicos de maximização de lucros. Nesta perspectiva, destacamse os estudos de Chandler (1962), Ansoff (1965) e Porter (1989, 1991), voltados à criação de modelos de planejamento estratégico racional para os estrtegistas, locados na alta administração. Conforme Chandler (1962), fazer estratégia é estabelecer metas e objetivos de longo prazo. Com este ideário, o estrategista deve ter controle sobre o meio externo, percebendo mudanças e aproveitando oportunidades. Porter $(1989,1991)$ propôs diversos modelos lineares, quantitativos pautados na constituição de estrategias competitivas. Segundo Clegg, Carter e Kornberger (2004), este enfoque se caracteriza pelo distanciamento da realidade organizacional. Os gestores viveriam uma fantasia de ordem, de projetos futuros e estratégias cuidadosamente planejada, em contradição com a realidade organizacional, caracterizada pela desordem, pela imprevisibilidade, pelos jogos de poder e pelas possibilidades concretas de implementação do planejado.

A partir da década de 70, surgem novos olhares, direcionados pela posição das organizações no meio e suas relações com este meio. A estratégia passa a ser analisada como produto de contextos específicos; portanto nem sempre previamente planejada, nem sempre sobre o controle e proposição da alta administração. Com este enfoque destacam-se Pettigrew (1977) e Mintzberg (1978). Mintzberg (1978) parte da ideia de que estratégia nem sempre pode ser planejada e a concebe como "um padrão em um fluxo de decisões” (Mintzberg, 1978, p. 935). No seu olhar, a estratégia se configura como processual, caracterizada ao longo do tempo. Mintzberg (1978) postula que as estratégias podem ser emergentes e/ou deliberadas. A ideia de estratégia emergente traz à tona a possibilidade de ações não planejadas, que se dão fora do controle racional, mas de carater estratégico, de adaptação da organização à realidade. A ideia de emergente traz também à tona o papel dos diversos atores organizacionais, que não os tradicionais estrategistas, na formulação das estratégias.

Pettigrew (1977), em seus estudos, propõe que a estratégia seja tomada como processo político, em que as decisões estratégicas, são realizadas contextualmente. As estratégias seriam processuais, e se referenciariam ao contexto em que se dão. Neste contexto, inclui-se desde a estrutura de poder na organização, a cultura organizacional, a estrutura organizacional, a atividade e o meio de atuação da organização. Ainda para Pettigrew (1987) os estudos sobre estratégia devem considerar a natureza contextual e processual da mudança estratégica, apreendendo os aspectos macro de contexto, isto é, a economia nacional; meso, isto é, o setor de atuação da empresa atua; e micro, isto é aspectos internos da organização.

O enfoque estratégia enquanto prática é mais recente; os primeiros estudos foram desenvolvidos a partir da década de 90 . Sua preocupação principal é com o fazer estratégia, com "os processos e as práticas detalhados que constituem as atividades diárias da vida organizacional e que se relacionam com os resultados estratégicos” (Johnson, Melin, \& Whittington, 2003, p. 14).

A análise da estratégia como prática, no campo dos estudos organizacionais, tem como primeira referência Whittington (1996, p. 731), com o artigo Strategy as practice (SAP) publicado no periódico Long Range Planning, que se propôs a responder as perguntas: “Que é estratégia? Quem a faz e como ela é feita?”. Buscando compreender estratégia a partir de um trabalho de observação próximo do estrategista, procura apreender os atos desenvolvidos por este na construção das estratégias. Para este 
autor, estratégia é compreendida como uma prática social. Para explicar o ato de fazer estratégia, ou estrategizar $^{(1)}$, Whittington (2002b) questiona onde, como e por quem esse trabalho é feito.

Onde. A estratégia é sempre situada, contextualizada, inserida no tempo e no espaço. Para Pettigrew (1977) a estratégia refere-se a um processo de eventos, que acontecem em um contexto. Para o autor, esse contexto é múltiplo, e se caracteriza por situar a estratégia no tempo; na cultura da organização; no ambiente em que atua, com seus níveis de mudança e resistência; na atividade, na estrutura e nas tecnologias da organização; no sistema de poder e na política interna da organização. Neste olhar, o contexto organizacional caracteriza-se pela articulação entre as ações cotidianas, as culturas existentes na organização e o meio de atuação em que a organização se insere.

Como se dá a estratégia? Toda a prática social é estratégica? Orientando essa linha de reflexão, há o conceito de práticas de Tuckermann Von Arx e Ruegg-Sturm (2006, p. 6):

atividades rotinizadas, regulares, desempenhos habilidosos de corpos humanos. Isso inclui modos de manuseio de certos objetos, assim como atividades intelectuais, como falar ou escrever ... Ao mesmo tempo, práticas são conjuntos de atividades mentais, implicando certas maneiras rotinizadas de compreender o mundo, de desejar algo.

Jarzabkowski (2005) diferencia prática e práticas. A prática pode ser entendida como atividade socialmente construída, práxis, processo em que o pensamento se realiza em ato, transformando-se em experiência. Enquanto as práticas (no plural) se referem às tecnologias, rotinas, normas, tradições, ferramentas, conceitos, ideias e procedimentos do qual os atores sociais lançam mâo na construção das estratégias. Nesta ideia a prática e as práticas tomam a feição de dois lados da mesma moeda, pois as normas, conceitos e ideias só têm expressão na realidade enquanto práxis? Como separar o ato do pensamento que o justifica e do processo que lhe deu origem?

Jarzabkowski et al. (2007) propõem que se adote a concepção de prática construída por Reckwitz (2002, p. 49) na apreensão dos atos estratégicos. Neste a prática é conceituada como:

Tipos rotinizados de comportamento que consistem de vários elementos, interconectados entre si, formas de atividades corporais, formas de atividades mentais, 'coisas' e seus usos, uma base de conhecimentos na forma de compreensão, saber fazer, estados emocionais e conhecimento motivacional.

Nesta perspectiva, a prática se refere a atos que se institucionalizam, agregando pensamentos, linguagens, costumes, conhecimentos, posicionamentos.

Este conceito de prática apresentado por Reckwitz (2002) e adotado por Jarzabkowski et al. (2007) carrega em si a ideia de intencionalidade nos modos de rotinização que o autor propõe como sendo "querer ou desejar certas coisas e evitar outras" (Reckwitz, 2002, p. 254). Essa intencionalidade deve ser estudada como conceito, pois influencia a diferenciação entre estratégias deliberadas e emergentes. Balogun, Huff e Johnson (2003, p. 199), quando se referem aos estados estratégicos, afirmam que é necessário "uma compreensão das intenções por trás das coisas que são feitas e das que não são". Wilson e Jarzabkowski (2004, p. 16) afirmam que, para compreender a "sabedoria prática", são necessários estudos detalhados das intenções dos estrategistas no uso de práticas interativas. Consequentemente, poderiam distinguir-se as diferentes práticas adotadas; haveria a possibilidade de diferenciar aquelas que se poderiam julgar como sendo estratégicas. Entretanto não se poderia afirmar que essa seria a única condicionante do conceito de prática que se poderia utilizar, para se entender melhor as práticas organizacionais.

Para Jarzabkowski, (2003), as práticas são socialmente definidas na medida em que o fluxo de atividade estratégica é construído. A estratégia aqui é apreendida como processual, não como sendo dada socialmente. Construída em processo de negociação entre os atores sociais, na visão da autora, as práticas se configuram em estratégia, à medida que se caracterizam como fluxo de atividades organizacionais, deliberado e emergente, ao mesmo tempo, que incorpora conteúdo e processo, pensamento e ação. 
Mas, por quem as estratégias são construidas? Fugindo de uma concepção de estratégia previamente definida, e entendendo a estratégia como processo que se configura no cotidiano organizacional, a estratégia só pode ser pensada como resultado de negociação entre diversos atores organizacionais. Para Jarzabkowski (2003), as práticas estratégicas referem-se à padrões de interação e interpretação, realizados no cotidiano de pessoas que compõem a organização. O foco é a prática social; o interesse se centra em como se desenvolve a prática, em como as pessoas fazem, ou seja no sujeito organizacional e nas suas inter-relações.

Jarzabkowski et al. (2007) os identificam como praticantes, atores sociais que se sustentam em práticas para agir e cujas atividades são fundamentais para a sobrevivência da organização. Os autores os definem como os indivíduos que moldam a construção da prática, em função de quem são, como atuam e dos recursos que dão suporte às suas ações (Jarzabkowski, Balogun, \& Seidl, 2006, p. 8).

Desta forma, neste nosso estudo, as estratégias serão apreendidas como práticas sociais resultantes de construções e reconstruções realizadas por sujeitos organizacionais, situados em contextos específicos.

No Brasil, o estudo de estratégias como práticas é recente. Walter e Augusto (2009) indicam que as primeiras publicações nacionais ocorrem a partir de 2004. Os autores acima citados podem ter o seu pensar resumido com a citação seguinte:

O tema de SAP [estratégia como prática] mais frequente nos estudos publicados no Brasil, assim como os do exterior, se encontra no strategizing. Neste tema, encontram-se estudos que buscam compreender como ocorre o processo de strategizing de forma geral ou mais específica, como é sua relação com a criação de identidades e com aspectos simbólicos, o strategizing de expatriados e a influência de stakeholders no strategizing. O segundo tema empregado é a relação entre o conceito de prática social e a disciplina de estratégia. Para discutir essa relação, os estudos se valem da teoria social e ressaltam as raízes de SAP em autores da sociologia, como Giddens, Bourdieu e De Certeau. Além disso, destacam a relevância do conceito de prática social para o entendimento da estratégia organizacional, observam como a estratégia é construída por meio de práticas sociais e dão destaque à relação entre estas e a estratégia. Outro tema identificado é o de possibilidades metodológicas, que inclui a indicação de metodologias e técnicas para os diferentes assuntos em SAP e da proposta de combinação da Grounded Theory e das narrativas de práticas (Walter \& Augusto, 2009 p. 14).

Assim, vários são os temas que percorrem os estudos da estratégia como prática e vários são os autores que são incorporados para dar maior abrangência ao significado de prática. Há também experiências em metodologias não usuais na área, tais como Grounded Theory e o uso de narrativas, indicando o uso de pesquisa qualitativa, corroborando metodologicamente com autores como Giddens, Bourdieu e Certeau.

O presente trabalho representa um esforço de analisar e estratégia como prática construida pelos diferentes atores organizacionais do Grupo Corpo, utilizando-se da Ground Theory. Ou seja, o desafio está em buscar capturar as práticas e seus significados para os membros do grupo de balé Corpo, com o intuito de apreender a construção da estratégia da organização. 


\section{Caminhos Escolhidos}

Nessa investigação, optou-se por combinar a etnografia e a análise situacional (Clarke, 2005), utilizando variadas técnicas de apoio, como a observação participante, entrevistas semiestruturadas, entrevistas de profundidade, pesquisa documental, fotografia e vídeo.

Observar como é a construção de estratégias na organização e entender como se constroem as práticas, a partir das atividades cotidianas dos membros da mesma, aponta caminhos para a observação participante. Entender os significados dessas práticas para os membros da organização e como esses significados são construídos indica uma necessidade de que essa observação não se restrinja aos fatos, mas que busque entendê-los na perspectiva dos atores envolvidos. Para cumprir esses objetivos, se adotou, como elementos metodológicos essenciais, a Etnografia e a análise situacional no enfoque da Grounded Theory, os quais serão descritos a seguir.

\section{Etnografia}

Na pesquisa de campo, a fim de compreender e apreender as práticas cotidianas, optou-se pela etnografia. Como processo, a etnografia é definida como o conjunto de técnicas para a coleta de dados, de forma bastante abrangente, sobre os aspectos culturais e comportamentais de um determinado grupo social, que pode ser desde uma tribo indígena, em sua acepção mais clássica, até uma sala de aula em escola de subúrbio (Aquino, 2001; Fetterman, 1998). Como resultado e registro, seria o relatório ou livro que centraria a narrativa na descrição do grupo social estudado, sustentado por teorias e/ou métodos empregados na investigação (Agar, 1980).

Quando abandona os próprios valores na interpretação de fatos observados, o pesquisador está adotando o que Agar (1980) denomina de perspectiva êmica, por tentar capturar a maneira como os membros de uma cultura percebem o seu contexto e lhe dão significado. Tal esforço demanda do observador não só a desconsideração de seus conceitos preestabelecidos, como também demanda a não leitura funcional dos fatos, que devem ser lidos a partir dos olhos do observado (Cançado, 1994).

Numa investigação etnográfica urbana, que caracteriza esta pesquisa no Grupo Corpo, a atitude de estranhamento se torna fundamental, visto que o observador está investigando, na maioria das vezes, organizações que estão inseridas no mesmo meio social em que ele vive. O processo de observação passa necessariamente por aquilo que Neves (2006) chama de estranhar o familiar e que, nesse caso, ocorrerá quase o tempo todo. Buscar o significado êmico, nesse caso, torna imperativa a compreensão dos fenômenos pela perspectiva do observado, desconsiderando a assunção dos próprios conceitos (Cançado, 1994).

No caso deste estudo, houve uma variabilidade entre os níveis de observação e de participação do pesquisador, dentro da prática da observação participante, os registros no diário de campo se tornaram cruciais para uma posterior análise dos fenômenos observados. O diário de campo, ou notas de campo, como as denomina Agar (1980, p. 112), são consideradas como o núcleo tradicional da pesquisa etnográfica, constituindo-se "no registro das observações do etnógrafo, conversas, interpretações e sugestões para informações a serem buscadas no futuro”. Dessa investigação resultou um registro feito em quatro diários de campo, 214 gravações de depoimentos espontâneos e entrevistas formais, 120 horas de vídeo e 11.000 fotografias, sendo 3.000 desses registros documentais.

\section{Grounded theory}

O método de Grounded Theory é utilizado pelas abordagens construcionistas, quando, ao estudar a realidade cotidiana das pessoas observadas ${ }^{(2)}$, o pesquisador busca: (a) familiarizar-se com o contexto, eventos e participantes no fenômeno observado; (b) focalizar nos significados e processos; (c) estudar os eventos e ações, com ênfase na compreensão dos processos sociais; (d) descobrir e detalhar o contexto onde ocorrem os fenômenos sociais observados; (e) prestar atenção na linguagem 
utilizada, pois "linguagem modela os significados e influencia as ações. Por sua vez, ações e experiências modelam significados” (Charmaz, 2005, p. 525).

A Grounded Theory é um método geral de análise comparativa que se aplica a qualquer conjunto de dados; é mais indicado para dados qualitativos. Esses dados são analisados sistematicamente mediante um conjunto de metodologias que têm por finalidade gerar teoria de modo indutivo em área substantiva, pelo ponto de vista dos atores envolvidos (Glaser, 1992, 1998; Glaser \& Strauss, 1967). Acrescente-se que a teoria gerada pelo método da Grounded Theory pode ser de dois tipos: formal, referindo-se à teoria desenvolvida para atender a uma área formal ou conceitual da pesquisa sociológica. A teoria gerada também pode ser substantiva, aquela desenvolvida a partir de uma área empírica ou substantiva da pesquisa social, sendo possível por meio de fatos para uma análise comparativa ou estudos etnográficos. Ressalte-se que a coleta direta de dados é extremamente útil para ela (Glaser \& Strauss, 1967).

No escopo da Grounded Theory, realizou-se a análise situacional para entender o ambiente organizacional, adotando-se o conceito proposto por Strauss de mundos sociais ${ }^{(3)}$ e arenas. Strauss (1978, p. 122) conceitua a sociedade como um coletivo de mundos sociais que não apresentam limites definidos: "em cada mundo social, pelo menos uma atividade primária (em conjunto com as atividades relacionadas) é extremamente evidente”. Ainda, segundo Clarke (1991), um mundo social não se delimita geograficamente ou por acordos formais, sendo um dos principais mecanismos que as pessoas utilizam para organizar suas vidas sociais.

\section{Quanto à arena, Clarke (1991, p. 128) diz que}

[ela] é um campo de ação e interação que ocorre entre uma potencialmente ampla variedade de entidades coletivas ... Conceitualmente, uma arena inclui todos os atores coletivos (sejam eles organizações, mundos sociais, movimentos sociais nascentes, ideologias ou tecnologias) comprometidos em agir dentro dela (da arena) ... O foco no compromisso para a ação como um delimitador da arena (ao invés de função ou área geográfica) permite a determinação empírica de quem - que entidade coletiva ou mundos sociais - está na arena.

Para realizar a análise situacional, Clarke (2005) propõe três abordagens cartográficas: (a) os mapas situacionais, que descrevem os principais elementos humanos, não-humanos ${ }^{(4)}$, discursivos e outros que ocorrem na situação de pesquisa, requerendo análise das relações existentes entre eles; (b) os mapas dos mundos sociais e arenas, referentes aos atores coletivos, elementos chaves não humanos e às arenas de comprometimento e discurso dentro dos quais aqueles elementos se engajam em negociações recorrentes; e (c) mapas posicionais, que descrevem as principais posições assumidas, e não assumidas, nos dados observados, contrapondo-se nos eixos de diferença, preocupação e controvérsia em relação às questões existentes na situação de investigação. Neste trabalho foi adotada a palavra esquema, em substituição a mapa. Segunndo Mora (2000, p. 893), “a noção de esquema está ligada à de forma e de ideia”, sendo aplicados à descrição de fenômenos, quando se busca uma explicação para eles e uma representação para o entendimento do que é observado.

Para se construir os esquemas situacionais, deve-se pensar em uma forma de representar todos os elementos humanos e não humanos importantes na caracterização da situação de pesquisa, como aqueles simbólicos e discursivos, respondendo às perguntas seguintes: "Quem e o que estão na situação? Quem e o que importa nesta situação? Que elementos fazem a diferença nesta situação" (Clarke, 2005, p. 87). Uma vez construídos os esquemas situacionais, organizados ou desordenados, o pesquisador precisa iniciar os questionamentos das relações entre eles. Os conceitos de mundos sociais, arenas e análise de discurso têm fortes raízes no interacionismo simbólico e enfocam especificamente grupos sociais construídos em função de significados compartilhados, resultando em coletividades variadas, pessoas que estão fazendo algo juntas, mas também podendo ser entendidos como universos de discurso (Clarke, 2005). Pode-se dizer que a força maior da produção de Grounded Theory reside nos níveis intermediários de análise, onde os mundos sociais e as arenas, como espaços simbólicos da ação social são elementos chaves na investigação. 
Assim, quanto aos aspectos metodológicos da pesquisa de campo, caracteriza-se que a base das análises de dados foram a Análises de Conteúdo e de Discurso. Como suporte da analise de conteúdo principalmente dos diários de campo - foi feita a análise temática. Segundo Minayo, Deslandes, CruzNeto e Gomes (1996) esta análise consite na identificação de núcleos de sentido que tenham algum significado para os sujeitos pesquisados. A análise do discurso foi usada na construção dos percursos semânticos, na análise dos intra e interdiscursos (Charaudeau \& Maingueneau, 2004). Ambas as análises foram usadas para a construção das práticas e de suas sustentações discursivas no cotidiano do Grupo Corpo.

\section{Construindo possiblidades de entendimento do Grupo Corpo}

Tomando como base a afirmação de Whittington (2002a, 2002b) de que estratégias são feitas por pessoas e que elas podem ser compreendidas pelo estudo das práticas identificadas em uma organização, foi realizada uma análise dessas práticas, a partir das relações construídas entre estas e os sujeitos que efetivamente as implantam na organização estudada. Assim, foi montado um esquema relacional entre as práticas encontradas e os atores individuais e coletivos, identificando aqueles que detinham o maior número de práticas e quais práticas eram mais importantes para o grupo.

A identificação dos elementos componentes de cada categoria fundamentou-se nas perguntas sugeridas por Clarke (2005), para saber quem e o quê estão na situação de análise (no caso, a organização Grupo Corpo); quem ou o quê importa nesta situação e que elementos fazem a diferença. Alguns elementos surgiram espontaneamente na análise dos códigos livres, todos derivados de análise de processos observados no Grupo Corpo; outros foram posteriormente examinados, no sentido de se identificar a congruência entre os códigos livres e os códigos axiais.

Para fazer a análise relacional das práticas, escolheu-se trabalhar com os atores coletivos principais da organização Grupo Corpo. São eles: (a) a administração do grupo; (b) a Escola de Dança; (c) a equipe técnica; (d) o núcleo de criação; (e) os montadores de espetáculos; (f) a produção geral; (g) o Corpo Cidadão; e (h) os bailarinos. Cabe ainda acrescentar que as práticas foram consideradas para cada ator coletivo, na medida em que, nessa prática o ator era agente implementador e não apenas participante.

\section{O Grupo Corpo: seus Mundos e sua Estratégia}

Conforme Bogéa (n.d.), o grupo Corpo é uma companhia de dança contemporânea, fundada em Belo Horizonte, em 1975.

A fundação do Grupo ocorreu por iniciativa de Paulo Pederneiras, que trouxe para a empreitada seus cinco irmãos e mais alguns amigos. Seus pais cederam a casa onde moravam para ser a sede do Corpo. Paulo Pederneiras, diretor geral, viria depois a assumir também a iluminação dos espetáculos; Rodrigo Pederneiras, que inicia como bailarino, será o coreógrafo de praticamente todos os trabalhos do Corpo a partir de 1981. Dos demais fundadores do Grupo vários permanecem até hoje: Pedro Pederneiras, Carmen Purri, Miriam Pederneiras e Cristina Castilho (Recuperado em 15 fevereiro, 2011, de http://www.grupocorpo.com.br)

Nestes 35 anos de existência, o grupo Corpo passou por transnsformações sucessivas, buscando estabilidade, identidade própria, e a continuidade do trabalho (Bogéa, n.d.). Envolvidos no grupo Corpo, há os cinco irmãos Pederneiras: Paulo (direção geral e artística), Rodrigo (coreógrafo), Pedro (direção técnica), José Luiz (fotografia) e Miriam (ex-bailarina, diretora da ONG Corpo Cidadão); e uma equipe fixa composta por: Carmem Purri (assistente de Rodrigo), Cristina Carvalho (Comunicação); Freuza Zechmeister (figurinista), Fernando Velloso (cenário e iluminação) e dezoito bailarinos. 
Hoje, três décadas passadas, o Grupo Corpo está definitivamente inserido entre as melhores e mais requisitadas companhias de dança do planeta. Mantém em repertório sete dos 32 espetáculos já montados e passa grande parte de seu calendário anual em turnês e apresentações internacionais (Recuperado em 15 fevereiro, 2011, de http://www.petrobras.br).

Em termos de estrutura organizacional, há o grupo Corpo de dança, a Escola de Dança Corpo, a ONG Corpo Cidadão e o Instituto Cultural Corpo, entidade sem fins lucrativos criada para gerir o empreendimento do grupo: o Centro de Arte Corpo, um complexo cultural em construção. O Grupo Corpo dispõe de patrocínio da Petrobrás, que se dirige ao grupo de dança, e ao Instituto Cultural Corpo.

\section{Esquema de mundos sociais/arenas do grupo corpo}

O objetivo da análise que identifica os mundos sociais e arenas é localizar "pessoas que fazem coisas juntas”, segundo Becker (1986, p. 33). Dessa maneira, segundo Clarke (2005), será possível entender como as pessoas se organizam e se ajustam aos esforços de outras pessoas que tentam organizá-las de forma diferente do que elas escolheriam, como horários de trabalho, pessoas com as quais irá trabalhar, entre outros fatores. Para entender os mundos sociais dentro da arena em que se situa o Grupo Corpo, é necessário entendermos quais os acordos coletivos de comprometimento são operacionalizados e quais os mundos sociais são proeminentes dentro da situação sob análise. Dessa forma, poderemos compreender as razões de existência dos mundos e submundos existentes na arena, onde o Grupo Corpo opera.

Como arena maior, onde o Grupo Corpo se situa, definiu-se o setor da cultura, especificamente o das artes cênicas. Segundo Porta (2008), esse setor abrange tanto a produção como a circulação e o consumo de bens e serviços culturais.

Com a intenção de descrever cada um dos mundos sociais que se relacionam ou fazem parte da organização do Grupo Corpo, e que se situam na arena das artes cênicas, foram utilizados os seguintes questionamentos: (a) Qual a função de cada mundo? (b) Quais são os comprometimentos coletivos assumidos por cada mundo? (c) Como os participantes do mundo julgam que devem agir, para dar conta de seu comprometimento? (d) Como cada mundo se vê em seu discurso? (e) Como cada mundo vê os mundos que interagem com ele? (f) Que ações têm sido tomadas e quais são antecipadas no futuro? (g) Como se organiza a agenda do mundo social? (h) Que tecnologias são usadas e implicadas na ação do mundo social? (i) Existem espaços específicos para organizar a ação do mundo em questão? Como eles são? (j) Que mais existe de importante na descrição desse mundo social?

A seguir, é apresentada a Figura 1 que representa o esquema dos mundos sociais que fazem parte do Grupo Corpo, ou interagem com ele dentro da arena das artes cênicas. 


\section{Arena das Artes Cênicas}

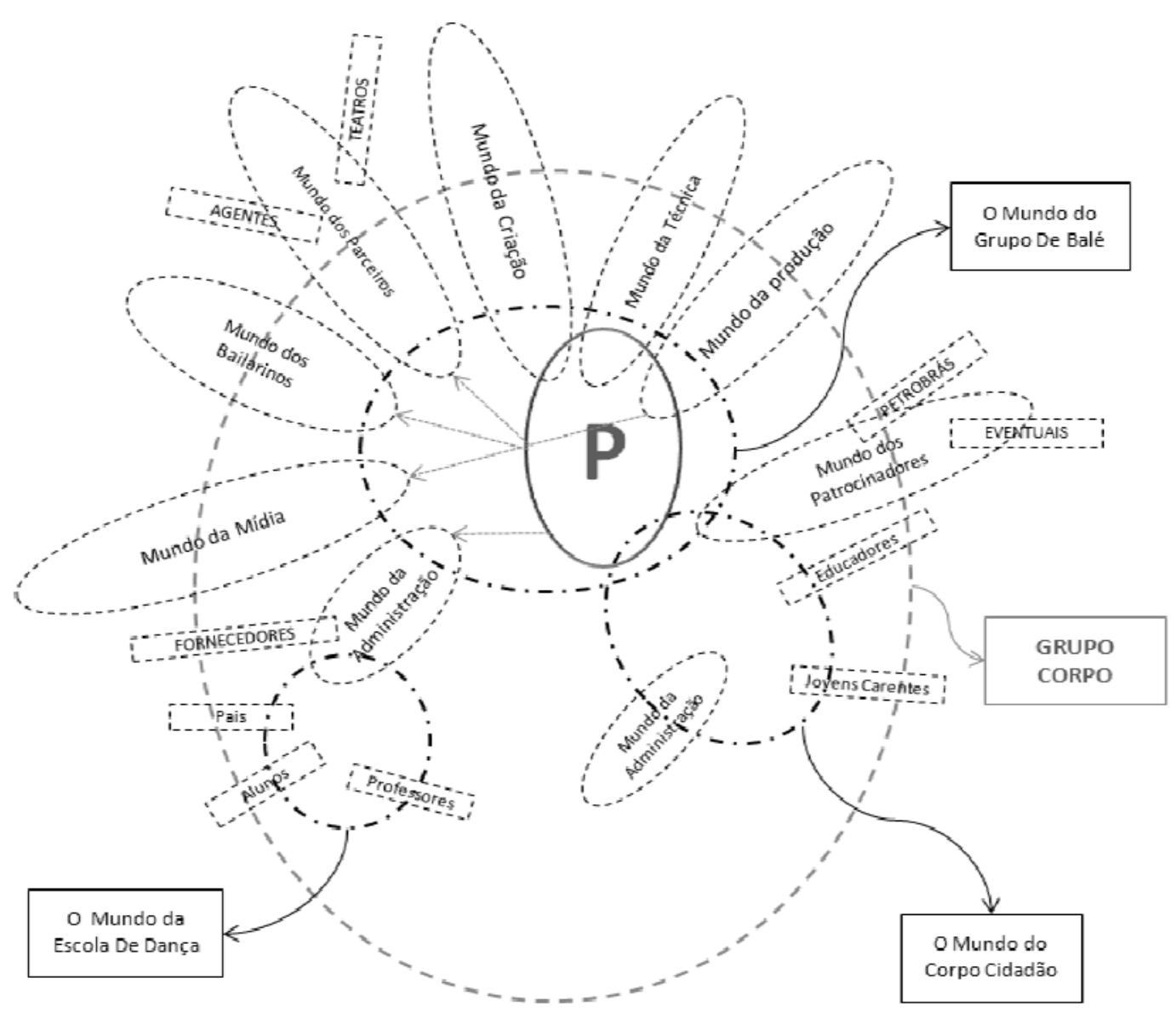

Figura 1. Esquema de Mundos Sociais e Arenas para o Grupo Corpo.

Fonte: Pesquisa de campo.

Na figura acima, as linhas tracejadas foram utilizadas propositadamente para reforçar a ideia de fluidez e baixo nível de delimitação existente em cada mundo social, havendo atores individuais e coletivos que transitam e operam em diferentes mundos, como se verá na descrição que será feita de cada um deles.

\section{O mundo Pederneiras (P)}

Caracterizamos como mundo Pederneiras (P), o grupo social composto por membros da família Perdeneiras, que estão diretamente envolvidos com o grupo Corpo. No Grupo de Balé, os três irmãos Paulo, Rodrigo e Pedro assumem a direção artística, a coreografia e a direção técnica, respectivamente.

Paulo Pederneiras é o diretor geral do grupo de dança, articulando o Mundo da Criação, o Mundo dos Bailarinos, da Técnica, da Produção, da Mídia, dos Parceiros e do Patrocínio. Assim como mantém uma relação de articulação entre o grupo de dança, a escola de dança e a ONG Corpo Cidadão. A gestão destes outros dois grupos é desenvolvida separadamente e independentemente, sendo, contudo, marcada pela identidade em comum: Corpo. O Instituto Cultural Corpo é uma entidade sem fins lucrativos, e tem o projeto e a administração da organização, sob responsabilidade de Paulo. Criado para administrar um grande complexo cultural, no qual o grupo de dança também pretende inserir-se, está em construção. 
Paulo está presente em todas as decisões que concernem à produção do produto de grupo: o espetáculo. Seja dando opniões sobre detalhes da coreografia, material a ser usado no cenário, discutindo o figurino etc... Paralelamente, assume também a função de iluminação do espetáculo.

A gestão dos recursos, a supervisão da área de comunicação, a organização de turnês internacionais e a relação comercial com patrocinadores (mundo dos patrocinadores) também são de responsabilidade de Paulo. Seu papel parece ser claramente o de articulador dos diversos mundos sociais.

Rodrigo Pederneiras é o coreógrafo da companhia desde 1978, quando fez Cantares, sendo raros os momentos em que foram convidados outros coreógrafos. Com formação em balet clássico, Rodrigo buscou aliar esta lingugem ao movimento corporal do brasileiro:

'nosso corpo' aprendeu a dançar na rua e a linguagem de Rodrigo, essencialmente moderna, abriga a seu modo o xaxado, o samba, as danças de salão, as festas, a capoeira. Tudo traduzido para um mundo particular, onde dinâmicas e desequilíbrios contam mais até do que as linhas do movimento (Recuperado em 17 fevereiro, 2011, de http://www.grupocorpo.com.br).

Conforme Katz (2000), o Corpo tem uma linguagem própria. Esta linguagem se sustenta na coreografia de Rodrigo, que traduz a música em movimento de forma singular. O grupo Corpo hoje teria um espaço consolidado no universo da dança nacional e internacional, devido a este processo autoral.

Há também Pedro Perdeneiras, responsável pela direção técnica dos espetáculos. Com formação em engenharia, atua especialmente na construção do cenário e da luz. Durante as turnês, supervisiona a montagem e desmontagem dos cenários e da luz, e coordena equipe de suporte, que vai dos figurinos, lanches, água e cuidados emergenciais que possam existir durante as apresentações.

Por sua vez, Miriam Pederneiras responsabiliza-se diretamente pela ONG Corpo Cidadão. A concepção e gestão cotidiana deste projeto são de sua responsabilidade. Neste projeto é responsável pela coordenação de oficinas, atividades de qualificação de jovens, grupos experimentais de dança, música e percussão, busca de patrocínio, projetos de formação de educadores sociais.

No grupo de dança, Miriam Pederneiras atua ocasionamente como assistente de coreografia e na Escola de Dança figura na direção.

Há uma atuação eventual de José Luís Perdeneiras, fotógrafo. Presente durante a fase final de construção de novas peças de balé, realiza a produção de peças fotográficas para a divulgação do trabalho do grupo na mídia.

Atua diretamente no dia a dia do grupo de dança também Gabriel Pederneiras, filho de Rodrigo, como coordenador técnico.

A presença dos Pederneiras só não acontece com maior intensidade no mundo da Escola de Dança, onde fazem intervenções eventuais, mas que têm o comando operacional dividido por Fernando de Castro, ex bailarino do grupo e Lelena Lucas, coordenadora pedagógica.

A imagem familiar é significativa e define parte da estrutura e das relações entre os atores sociais envolvidos. Nesse sentido, a família, como tema, inspirou um documentário sobre os 30 anos de existência do grupo, denominado Grupo Corpo, uma família brasileira. Oscar Araiz já antecipava o significado simbólico das relações do grupo quando disse que, além de uma organização, "[o Corpo] é uma família, em diversos níveis: uma família de sangue e de ideias e também uma família de sensibilidade” (Araiz em entrevista a Vilela, 1980, p. 39).

José Miguel Wisnik, músico, convidado a compor para vários espetáculos do grupo Corpo, relata este caráter de família do grupo Corpo: 
essas conquistas do Grupo Corpo nos fazem pensar não só no resultado final que eles apresentam, mas pensar que processo possibilitou uma consolidação desse tipo. No Brasil, em geral, é muito difícil sustentar o trabalho de grupos continuados e dar a eles consistência e qualidade, porque, muitas vezes, esbarra-se nas condições da produção, que impedem que um trabalho desse tipo tenha a consistência que o Grupo Corpo tem, graças a uma continuidade. Entretanto, há muitos anos, eles o vêm fazendo, e vejo que isso só foi possível porque é um grupo extraordinário de pessoas que expandiu um núcleo familiar. Acho que por trás disso tem algo do mistério da família mineira, porque na verdade foram irmãos que se interessaram pela dança e constituíram uma célula inicial de pessoas que passaram a estudar dança, trabalhar com a dança e fizeram um espetáculo que tinha irmãos e irmãs atuando como dançarinos. Um deles tornou-se coreógrafo, que é o Rodrigo Pederneiras. Outro se tornou diretor artístico do grupo. Tudo isso talvez pedisse algo do tipo o desejo de fazer um trabalho com dança; mas também essa agregação de tipo familiar, que em Minas é possível, não só por ser a família Pederneiras, mas também porque ela acaba congregando outras pessoas que também passam a viver de uma forma de muita sociabilidade, de sensibilidade familiar (Wisnik, 2000).

\section{O mundo do Grupo de Balé}

Esse mundo tem em sua composição os seguintes submundos: mundo dos bailarinos, mundo da criação, mundo da técnica, mundo da produção e mundo da administração. Ele também tem uma interface importante com o mundo da mídia e com o mundo do Corpo Cidadão. Sua função essencial é apresentar espetáculos de balé. Para isso, há forte dependência da ação de todos os submundos que o constituem.

Até o ano de 1984, seu discurso era o de capacitação, da preocupação continuada de formação dos membros do grupo, envolvendo esforços massivos de todos os seus submundos, orientados para uma aprendizagem acelerada, obtida nos diversos teatros em que atuou com o espetáculo Maria, Maria. A partir do ano de 1984, seu discurso incorpora a temática do patrocínio, da preocupação com a continuidade, segurança, estabilidade tornada possível com a criação da lei de apoio e incentivo cultural promulgada por José Sarney. De 1989 a 1999 obtém o patrocínio da Shell e, a partir de 2000, o patrocínio da Petrobras.

Em relação a esse mundo, pode-se caracterizar o mundo dos bailarinos como de atores coletivos implicados e silenciosos. A relação do mundo do Grupo de Balé com seus patrocinadores possui ambiguidade discursiva. Se, de um lado, o discurso confirma a dependência financeira para com o patrocinador, por outro há críticas na maneira como se constrói a contrapartida, especialmente no que se refere à autonomia de criação.

A preocupação permanente desse grupo está centrada na diferenciação de sua imagem no setor de artes cênicas, tendo-se utilizado principalmente do discurso da identidade estética como forma de caracterização e identificação do Grupo Corpo nesse cenário. A agenda de trabalho do Grupo de Balé tem um planejamento minucioso que se estende, em média, por dois anos à frente, em relação às apresentações. De dois em dois anos, sua agenda se ajusta à agenda do mundo da criação, que utiliza aproximadamente um semestre a cada dois anos para a construção de um novo espetáculo..

O mundo da criação é o motor da construção identitária do Grupo Corpo. A ação cobrada pela direção artística para os membros desse grupo é um permanente desapego ao que já foi feito. As propostas de criação de cenário, coreografia, figurino, material de divulgação, iluminação, são executadas sem caráter definitivo, podendo ser revistas em prol de um resultado que se possa figurar superior no decorrer da construção do espetáculo.

Todas as atividades do mundo do Balé se voltam à produção do espetáculo. A construção de espetáculo começa na escolha de um compositor para realizar a música. A escolha do compositor geralmente é feita pelo núcleo Rodrigo, Carmem, Paulo e Pedro. Não há pressupostos anteriores, nada mais do que o desejo de experimentar a dança sob o som de um compositor especifico. A este também 
não lhe é solicitado nada de especifico, além de uma composição, não há tema anterior. Conforme Rodrigo:

"É as pessoas que a gente, a gente sempre tem um monte de gente na cabeça e claro que o Lenine era um deles; mas eu decidi chamar o Lenine foi o que ano passado mesmo, início do ano passado ... ó porque eu gosto muito, só por isso. Eu gosto muito. Claro que é por uma série de coisas, eu gosto da força que a música dele tem, a música tem uma força especial, tem um monte de coisas, a gente gosta de Zé Miguel e Caetano, é porque a gente gosta deles, da musica deles” (Rodrigo).

"As coisas é que vão encaixando com o que a gente, é verdade, é boa essa ideia de você se, se influenciar, se deixar influenciar, deixar com que as pessoas mexam com você, eu acho isso muito bom, agora essa idéia de fazer um balé sobre violência; por exemplo, quando eu chamei o Lenine, eu não pensava nisso,(...)".

O tema surge no decorrer da composição e dos diálogos que o músico estabelece com o grupo Corpo. A partir da música, Rodrigo Pederneiras cria movimentos, trechos de movimentos, acompanhados por Macau (Carmem Purri) e Miriam Pederneiras.

São 18 bailarinos que ensaiam continuamente sob a supervisão de Carmem Purri (Macau), exbailariana e assistente de Rodrigo Pederneiras, uma das fundadoras do Grupo; ela tem como papel trabalhar, elaborar o movimento, cuidar para que se realize como proposto pelo coreógrafo. Macau é quem traduz o pensamento de Rodrigo para uma velocidade que os bailarinos consigam assimilar. E depois, é dela a responsabilidade de sincronizar e ajustar os movimentos, dentro da música, conforme a intenção de Rodrigo. Sua presença é fundamental, quando se pensa em remontar balés já apresentados. Macau tem ótima memória e muita paciência para demonstrar os detalhes de cada trecho de balé, onde os bailarinos demonstram dificuldade de aprendizado.

O grupo de bailarinos submete-se a uma rígida disciplina de ensaios contínuos, por seis meses, associada a aulas diárias de balé clássico.

Depois da definição da coreografia, intervém na construção do espetáculo Freusa Zechmeister, responsável pelos figurinos, Paulo Pederneiras na iluminação e Pedro Pederneiras no Cenário. A concepção é de cada um; contudo a definição de caminhos a seguir e a escolha /decisão final é coletiva. Bailarinos opinam sobre figurinos, tanto no aspecto conforto (facilidade do movimento) e estética. No cenário, iluminação, material publicitário, opinam todos os que estiverem no mesmo espaço, nos momentos de definição.

Ressalta-se que, nas definições de cunho estético, as discussões tendem a centrar-se no núcleo original do Grupo Corpo: Paulo, Pedro e Miriam Pederneiras, e Carmem Purri, com a participação ocasional de Freusa Zechmeister, na discussão de figurino.

A sintonia entre os membros do grupo é alta e há o consenso de que o resultado final é o que define onde o conjunto deve ser modificado. Apesar de não se ter uma ideia clara do que será o resultado, o grupo desenvolveu uma sensibilidade estética apurada para examinar elementos do conjunto e descartar aqueles que, na percepção deles, poderão influenciar negativamente o resultado. Essa visão de futuro, construído a posteriori, é o que influencia a decisão do núcleo de criação sobre a permanência, alteração ou exclusão de elementos componentes seja do cenário, seja da iluminação, do figurino ou da coreografia. Esse processo de ajustamento e retirada do que sobra, nas palavras de Paulo, é denominado no discurso deles como a limpeza do espetáculo.

Definidos todos os elementos da criação do espetáculo, o grupo passa a ensaiar uma peça anterior. Desde 1984, o grupo adota a prática de apresentar um programa duplo. Sua intenção é apresentar o novo espetáculo, com o respaldo de outro espetáculo anterior que tenha sucesso de público.

Antes da apresentação do espetáculo, é construído um grande aparato publicitário midiático, coordenado por Cristina Castilho, responsável pela área de comunicação. Nestes há a preocupação de apresentar uma imagem do grupo, com grande qualidade estética. 


\section{O mundo da Escola de Dança}

A Escola de Dança relaciona-se à formação artística e aperfeiçoamento de bailarinos e coreógrafos, tendo como referência principal a imagem de excelência artística do Grupo Corpo, construída a partir de seu Grupo de Balé.

Para manter essa imagem, os atores da escola estão permanentemente engajados em construir ideias para workshops e oficinas de dança. Cabe também citar os Encontros de Dança Contemporânea e o encontro denominado Dança em Setembro, que são promovidos anualmente pela escola, sempre variando as temáticas escolhidas e os nomes dos músicos, coreógrafos e especialistas das áreas de artes cênicas que são convidados para proferir palestras.

Em seu discurso, os atores do mundo da Escola de Dança assumem uma dependência crônica da imagem do Grupo Corpo, considerando-a importante para o futuro da escola. O fato de haver uma possibilidade concreta de uma separação física entre a escola e o Grupo de Balé se configura como uma visão de futuro sombria para a existência da escola. Os atores acreditam que essa separação física provocará um distanciamento que impactará na imagem da escola que, em seus discursos, tem uma vinculação forte e mítica com o Grupo de Balé. Sua agenda é construída com liberdade.

Entretanto a direção da escola está permanentemente pesquisando novas informações e construindo novas redes de contatos. Esta ação possibilita o acesso da escola a novas fontes de aprendizado, tanto para seus alunos como para a comunidade em geral, interessada em artes cênicas. Para suas aulas, a Escola de Dança utiliza as duas salas de aula de balé no segundo andar da sede do Grupo Corpo e, eventualmente, o teatro do terceiro andar. Nas palavras de sua coordenadora pedagógica, a Escola de Dança Corpo "desenvolve uma visão mais crítica e contextualizada da dança e das artes em geral nos seus alunos”.

\section{O mundo do Corpo Cidadão}

Em 1998, Miriam Pederneiras se engajou em projeto de inclusão social, o Sambalelê, que propõe a utilização do aprendizado da arte como instrumento de inclusão e de conscientização, tendo como publico crianças e adolescentes oriundas de áreas de vulnerabilidade e risco social em Belo Horizonte e seu entorno. Assim, iniciando o trabalho na favela denominada Aglomerado da Serra, atinge aproximadamente 800 crianças.

O comprometimento dos atores envolvidos nesse mundo é o de propiciar aos jovens que se encaixam no seu perfil de atuação, condições de aprendizado de música, dança e outras manifestações artísticas como forma de recuperação. São 50 profissionais contratados que se revezam em apoio pedagógico, aulas, suporte familiar e diversos tipos de orientações, além de fornecer alimentação e abrigo aos que se encontram nos locais onde a ONG atua. Entre seus colaboradores há alguns que são ex-bailarinos do Grupo Corpo, desempenhando o papel de professores de dança para os jovens participantes.

Verifica-se, contudo, que a força do nome do Grupo Corpo fundamenta a relação construída com o seu principal patrocinador, a Petrobrás, assim como as relações construídas com outros eventuais colaboradores, como a Usiminas. Como a ONG não tem nenhuma fonte de receita, sobrevive exclusivamente à custa dos patrocínios obtidos, passando por períodos de absoluta ausência de condição financeira, em toda a renegociação de verbas com a Petrobrás. O Corpo Cidadão não trabalha com uma perspectiva futura muito concreta, havendo poucos significados construídos em sua visão de futuro, além da incerteza de continuidade. Sua agenda de compromissos sociais é feita sob a restrição imposta pela liberação de verbas pela Petrobrás. É importante notar que o seu submundo da administração é totalmente separado do que gerencia financeiramente o Grupo de Balé e a Escola de Dança. 
Como tecnologias implicadas em sua ação social, estão todas aquelas utilizadas na produção e aprendizado de artes cênicas em geral e artes musicais. Os espaços de atuação são um escritório montado na Serra e em mais três endereços de atuação nos bairros, onde as crianças e adolescentes participantes de seus programas vivem. O Corpo Cidadão ainda se utiliza das dependências do Palácio das Artes para aulas de balé com os jovens e, eventualmente, da sede do Grupo Corpo.

\section{Respondendo às Perguntas sobre Estratégia}

Buscando responder às perguntas orientadoras deste trabalho de pesquisa (expostas no primeiro parágrafo da introdução), torna-se necessário apoiar-se essencialmente nas práticas observadas e na forma como elas se relacionam com os três mundos organizacionais identificados no Grupo Corpo: o mundo do Grupo de Balé, o mundo do Corpo Cidadão e o mundo da Escola de Dança, os quais estão representados na Figura 2 a seguir:

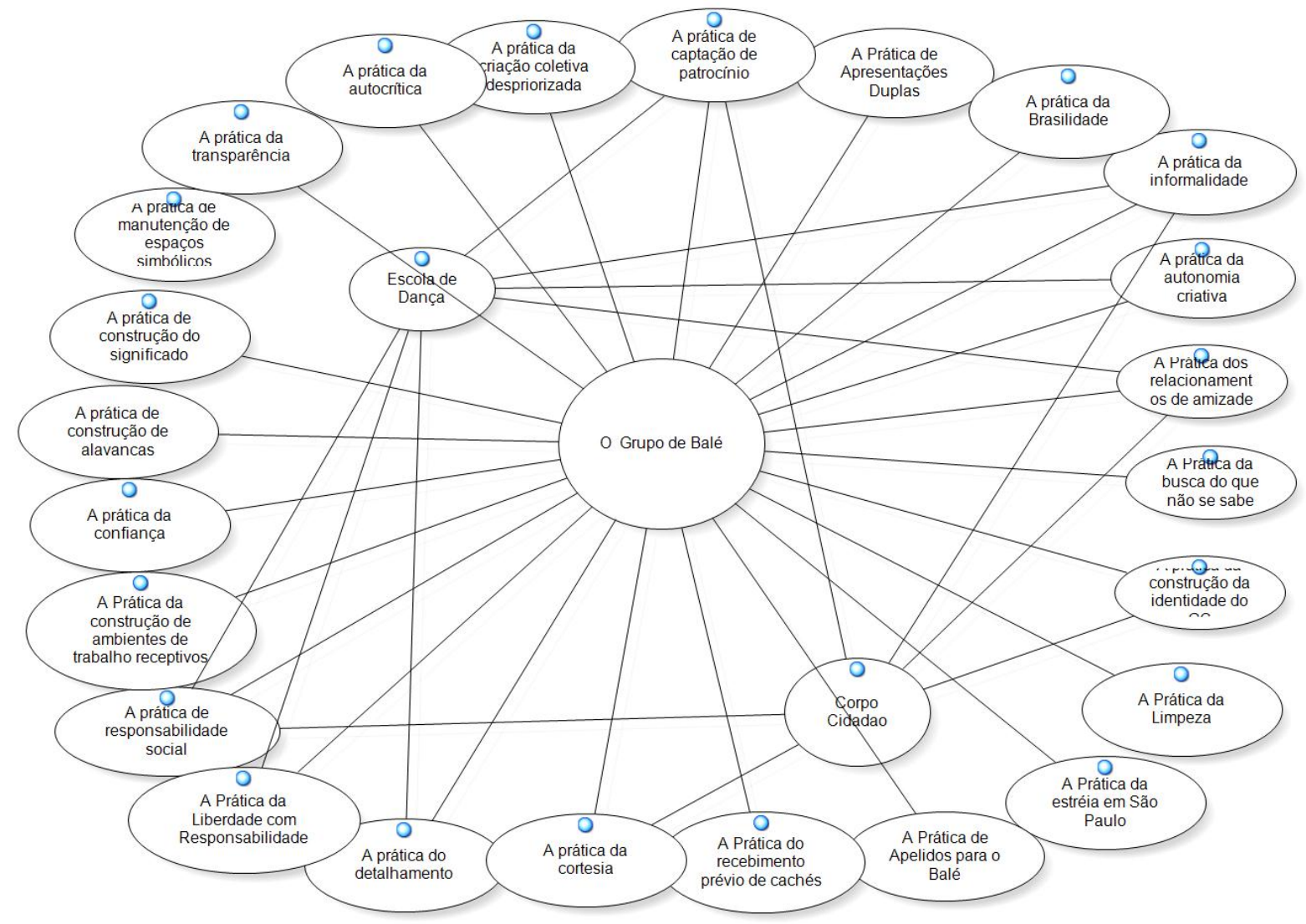

Figura 2. Análise Relacional das Práticas com os Mundos do Grupo Corpo.

Fonte: Pesquisa de campo.

\section{Sobre as práticas}

No decurso de codificação da análise situacional, foram identificadas 24 práticas, posteriormente apresentadas e analisadas em conjunto com Paulo Perdeneiras, diretor artístico do Grupo Corpo, escolhido como referência para a análise de quais práticas eram consideradas estratégicas para o grupo. Observou-se que não havia critérios objetivos, por parte de Paulo Pederneiras na avaliação e escolha de quais práticas ou ações podem ser julgadas "consequenciais para resultados, direções, sobrevivência ou vantagem competitiva em uma dimensão estratégica” nesta organização (Jarzabkowski, Balogun, \& Seidl, 2007, p. 8). Para estes autores, a definição de quais práticas podem implicar nos resultados, direções, sobrevivência ou vantagem competitiva pode levar a 
uma descoberta de efeito borboleta ${ }^{(5)}$. Qualquer ação, qualquer decisão dentro da organização ou prática identificada pode ser julgada como sendo consequencial, banalizando o esforço de identificação de práticas que sejam estratégicas: tudo seria estratégico e, sendo assim, não teria sentido estudar esse conceito. Se a opção for por adotar algum critério de importância, para definir quais práticas seriam estratégicas, pode ocorrer que, práticas entendidas pelo observador como importantes, podem ter, na opinião dos gestores da organização observada, uma avaliação de pouca ou nenhuma importância. Para evitar essa ambiguidade, optou-se nessa pesquisa por respeitar as escolhas e avaliações do gestor da organização.

Quando se coloca o conjunto das práticas identificadas na pesquisa etnográfica e na codificação axial em relação aos mundos que compõem o mundo Grupo Corpo, observa-se que há uma concentração de práticas voltadas para o mundo do Grupo de Balé, sendo que a maior parte dessas práticas ocorre exclusivamente dentro desse mundo. Contudo, algumas dessas práticas, ao se localizarem dentro do mundo do Grupo de Balé, não excluem ações direcionadas para o mesmo objetivo dentro dos outros mundos. O que ocorre e que torna a prática diferenciadora é que ela é continuamente praticada dentro do mundo do Grupo de Balé, além de fazer parte do discurso diferenciador desse mundo. Na Escola de Dança, perceberam-se ações com o mesmo sentido; no entanto não há elementos discursivos nem a intensidade ostensiva que ocorre no mundo do Grupo de Balé.

Identificamos diversas práticas durante a construção do espetáculo Breu, espetáculo em construção por ocasião da pesquisa de campo. Observaram-se vários atos institucionalizados, que compõe o cotidiano da organização. Exporemos os mais frequentes e, de certa forma, mais particulares, próprios, da organização grupo corpo e avalizados por Paulo Pederneiras.

Na comunicação das pessoas, predomina a prática da informalidade, que se encontra diluída em processos encontrados, tanto na Escola de Dança como na ONG Corpo Cidadão e no grupo de balé. Não há regras preestabelecidas de comportamento e linguagem, funcionando como normas para as relações, assim como não se percebem práticas gerenciais de incentivo ou de cerceamento à prática da informalidade que surge espontaneamente nas relações internas e externas do Grupo Corpo.

$\mathrm{Na}$ construção do espetáculo, prevalece a prática da autonomia criativa de forma institucionalizada. Parte-se do preceito de que todos são criativos e há liberdade para expor suas ideias, assim como há espaço para a incorporação das ideias de todos. Conforme os próprios membros do grupo reconhecem, há incentivo permanente à crítica e à busca de algo novo, evidenciado no discurso de Paulo Pederneiras: "o que interessa é o que não se sabe fazer”.

O núcleo de criação é um dos atores coletivos que exercita um dos maiores números de práticas no Grupo Corpo. Além de trabalhar em alto nível de informalidade, mesmo nas relações com os bailarinos, em que eventualmente ocorrem alguns ajustes, eles detêm alto nível de autonomia criativa. A prática da busca do que não se sabe é uma constante no grupo, proporciona constante reavaliação do que está sendo construído, submetendo o que está feito a severos níveis de autocrítica. Para isso a confiança total na visão e senso estético dos colegas do grupo é fundamental.

Essa forma de trabalho, aliada a uma constante evolução no trabalho coreográfico, é o que dá os contornos mais nítidos da identidade estética do grupo. Posteriormente, essa construção estética tem seu significado construído de acordo com as escolhas feitas pelos membros do grupo. Na maioria das vezes, essa construção de significados tem a colaboração dos compositores das trilhas. A música e a coreografia, que vai sendo construída com base nela, dão a direção do que se pretende, de quais significados se pretende expressar.

No processo de criação, há a prática de construção de futuro a posteriori dado que não há definição de elementos de antemão, predeterminados, é no processo que vão sendo definidos os elementos constituitivos do espetáculo. A decisão do núcleo de criação sobre a permanência, alteração ou exclusão de elementos componentes, seja do cenário seja da iluminação, do figurino ou da coreografia, só tem como norteador um ideal estético. A construção de um produto final é direcionada 
pela busca de uma identidade própria com vínculos na cultura brasileira, assim como há uma exigência própria de busca de constante aperfeiçoamento, de superação, de diversificação em relação a trabalhos anteriores.

No mundo da técnica, responsável por viabilizar as construções do mundo de criação não existe o discurso da liberdade com responsabilidade. No caso do mundo da técnica, o discurso remonta à administração científica, com cobrança de horários rígidos de trabalho e de prazos e eficiência na execução de determinada tarefa.

No mundo da produção geral, que opera com um planejamento para prazos de dois a três anos, realizam-se práticas importantes para o Grupo Corpo. Destaca-se a prática de apresentações duplas, que se configurou como estratégia para atribuir segurança ao grupo. As apresentações duplas permitem a possibilidade de ousar, na apresentação de um novo número com o respaldo de aceitação de publico e uma peça anterior.

Destaca-se a ideia de coletivo, de produção coletiva, em que atores sociais dos diversos mundos da organização tendem a ser vistos e tratados como componentes deste coletivo. Na produção do espetáculo, há uma orquestração da diversidade de pessoas e atividades que participam da produção coletiva.

O grupo tem duas práticas que chamam a atenção pela importância que têm na imagem interna de relacionamentos e na relação com os patrocinadores: a prática da transparência e a prática da confiança. Os gestores do grupo fazem questão de permitir acesso de todas as pessoas interessadas às informações existentes dentro da organização. Neste sentido, durante a realização da pesquisa de campo, sempre houve resposta para qualquer tipo de informação solicitada. $\mathrm{O}$ acesso era tamanho, que foi permitido conhecer dois auditores e conversar com eles: atuavam no Grupo Corpo, fazendo análise das prestações de contas e dos registros fiscais da organização.

Da mesma forma, é de notar e destacar como as práticas de confiança estão presentes nos relacionamentos internos do grupo. Os dois administradores da parte financeira têm autonomia para a movimentação financeira de pagamentos e recebimentos em nome do grupo, podendo assinar individualmente documentos em nome do grupo.

Durante a observação etnográfica, percebemos que as práticas do Corpo Cidadão são, em sua maioria, oriundas da vivência que a sua coordenadora, Miriam Pederneiras, teve e ainda tem no Grupo Corpo. Observa-se na Figura 2 que somente há três práticas comuns aos nos três mundos: a prática de captação de patrocínio; a prática de relacionamentos de amizade e a prática de responsabilidade social. Um dos problemas que impactam a ação da ONG Corpo Cidadão é o fato de que a dependência da verba oriunda de patrocínio é total, tanto do Grupo de Balé como da Escola de Dança. Esse mundo Corpo Cidadão ainda não tem capacidade de gerar receita e não se percebem práticas desenvolvidas de modo consistente, que tornem seus gestores capazes de lidar com essa situação, sem enfrentar crises sazonais constantes, que se têm se repetido desde a fundação da ONG, em 2000.

Em termos de dimensão futura, os três mundos organizacionais têm posições totalmente contrastantes na construção de seu significado. Se no mundo do grupo de balé, como organização, a questão de futuro tem propostas sólidas de outros caminhos alternativos para a continuidade da organização, para transformá-la, o mesmo não se pode dizer com relação ao mundo do Corpo Cidadão, diferente também da Escola de Dança.

No grupo de balé, há discursos localizados que pensam como se manteria a identidade do grupo, numa eventual ausência de Rodrigo, o coreógrafo. Miriam Pederneiras tem pensado eventualmente em produzir um registro escrito, em forma de pesquisa e publicação de um livro, para explicar a técnica de criação do Rodrigo, mas não existem ações direcionadas à operacionalização dessa intenção.

No grupo de bailarinos, quando algum percebe sua potencialidade como coreógrafo, não existem práticas direcionadas ao incentivo dessa habilidade, fazendo com que esses potenciais sejam perdidos com a evasão, como aconteceu com o bailarino Rui Moreira, que saiu do grupo para fundar 
sua própria companhia, a Seraquê, e Peter Lavratti, que saiu no ano passado para tocar projetos pessoais de construção de peças de balé.

Os gestores da Escola de Dança lidam com o futuro de curto prazo, mantendo uma visão ligeiramente pessimista do futuro, em função da possível mudança de sede do grupo de balé. É provável que seus gestores tenham de repensar suas práticas de gestão caso essa mudança venha a se concretizar; mas não se perceberam práticas orientadas ou construídas em função desse futuro.

Em face do exposto, pode-se afirmar que houve uma sistemática construção de teorias quando se reorganizaram os dados levantados do Grupo Corpo, de modo a descrever os processos internos e identificar as práticas de seus gestores. Ao propor uma resposta para o que é estratégia, pode-se afirmar que ela decorre de uma interpretação das práticas observadas, aliada às dimensões percebidas como presentes nas definições usuais de estratégia.

Na construção desse conceito substantivo buscou-se construir um parágrafo que contemplasse, de alguma maneira, todas as práticas observadas e julgadas como estratégicas, no mesmo tempo em que se situassem no escopo das quatro dimensões comuns dos conceitos de estratégia. Baseado nesses objetivos argumentados, propõe-se que estratégia, com base nas práticas identificadas nas ações, decisões e discursos analisados na investigação de campo, realizada junto ao Grupo Corpo, seja conceituada como se explicita em seguida.

Construir objetivos, aperfeiçoando processos, angariando apoios consistentes e limpando os caminhos escolhidos, removendo tudo o que não se configure como a melhor escolha, com base em um senso estético de resultado futuro indesejado, definido a posteriori e mantendo tudo o que assegure eficiência processual, ou que favoreça a satisfação em sua execução, sem, entretanto, mecanizar os processos ou cair na repetição, assegurando-se que todos compreendam e reconheçam claramente as intenções e escolhas via ações e discursos de confirmação de propósitos.

As escolhas e as práticas cotidianas do Grupo Corpo se configuram como a expressão de um pas-de-deux da estratégia com a arte. PAS DE DEUX refere-se aos passos, movimentos rítimicos, realizados por dois bailarinos. Podemos considerar que o grupo Corpo desenvolve diversos movimentos (práticas), que buscam congregar a arte (busca de sua identidade) e a estratégia (busca de sua continuidade no tempo). Um Pas de Deux da estratégia com a arte.

\section{Considerações Finais}

Observando o percurso realizado nesse trabalho de pesquisa, é necessário tecer algumas considerações com relação à perspectiva teórica, às escolhas metodológicas e aos objetivos assumidos para a investigação de campo e análise de dados. Desde a construção do referencial teórico, no qual se pretendeu aliar a teoria desenvolvida no campo da estratégia, notadamente para estratégia como prática à direção metodológica, adotada para construir a análise de dados, houve uma sucessão de descobertas que reforçaram a ideia de que a proposta tinha coerência teórica e possibilidades de aporte ou contribuição ao trabalho científico na área da administração, especificamente na teoria da Estratégia como Prática.

Considerando que o conceito de prática, proposto por Reckwitz (2002), em si não é suficiente, pela sua amplitude para indicar que práticas seriam estratégicas. Essa adoção implicou a identificação de práticas que, ao serem apresentadas aos membros do Grupo Corpo, não foram validadas como sendo práticas importantes. Esse confronto de interpretações foi importante e consideramos que ele foi suficiente para diferenciar práticas estratégicas de práticas que não o são. Dessa forma, essa escolha confirma a atribuição ao gestor do controle sobre a estratégia, como Whittington (1996) julga importante para estudar estratégia como Prática. 
Quanto ao objetivo proposto para essa pesquisa - conceituar estratégia de maneira substantiva, a partir da observação das práticas do Grupo Corpo - é possível afirmar que ele foi alcançado não só por uma construção semântica, como a que foi apresentada no término do capítulo anterior, mas pelo fato de que as perguntas orientadoras, formuladas para atender ao objetivo geral, também tenham sido respondidas: Que é estratégia? Quem é o estrategista? Que fazem os estrategistas?

As práticas identificadas possibilitaram inferir que a função de estrategista é papel desempenhado situacionalmente por diversos atores. Além disso, a função em si é decomposta em variadas formas de agir, que vão da criação de práticas estratégicas até a sua formulação e implantação. Atenção especial foi dada também ao discurso estratégico que, no Grupo Corpo, se configura como prática consistente e efetiva na construção da imagem e identidade estética.

A constatação de que a função estrategista pode ser atribuída a diferentes atores leva à segunda pergunta sobre quem é o estrategista e dá pistas de quem seria o estrategista, na verdade, os estrategistas. Basendo-se na prática discursiva dos membros da organização, aponta-se Paulo Pederneiras como o principal estrategista do Grupo Corpo. Sua ação como líder é reconhecida de maneira consensual e é executada sem enfrentamentos ou questionamentos, prevalecendo um senso comum de que várias proposições e ações estratégicas passam por um crivo decisório deste gestor. Entretanto, ao se examinar os que implantam as práticas e os que as formulam ou criam, observa-se que nem sempre a ação descrita está vinculada à figura do Paulo. Em algumas práticas, percebe-se que sua atuação é literalmente nula e, no entanto, a prática está institucionalizada e é reconhecida como prática importante para o sucesso e a história do Grupo Corpo. Há outras práticas estratégicas, que são formuladas por um ator especifico e têm a decisão de implementação no coletivo não formal do núcleo de criação do grupo, especialmente formado pela família dos Pederneiras.

A influência de Paulo como principal estrategista está explicitada no registro do mundo Pederneiras. Na análise situacional, foi identificado esse mundo familiar, sem um arranjo formal distinto dentro da organização, mas com ramificações e influência direta no mundo do grupo de balé e no mundo Corpo Cidadão. O mundo Pederneiras exerce influência importante nas práticas do Grupo Corpo e nos caminhos adotados pela organização, principalmente no que tange ao seu futuro.

Quando se analisa a forma como as práticas ocorrem, nos três diferentes mundos organizacionais identificados dentro do Grupo Corpo, o mundo do grupo de balé, o mundo da Escola de Dança e o mundo do Corpo Cidadão, percebe-se que a organização tem direcionado seus esforços estratégicos para o mundo do grupo de balé, já que, das 24 práticas identificadas na pesquisa, somente uma, a de manutenção de espaços simbólicos, não tem relação direta com o grupo de balé. Diga-se de passagem que essa prática se institucionalizou em um nível tácito, de modo que ela não se vincula a nenhum dos três mundos organizacionais.

Já a Escola de Dança, de forma consistente e identificada nos discursos de seus gestores, tem vinculação com sete práticas principais. Apesar do baixo número de práticas, comparando-se ao grupo de balé, todas elas têm resultados benéficos para esse mundo, no entender de seus gestores, porque influenciam de maneira positiva a história e os processos organizacionais da Escola de Dança.

O mundo do Corpo Cidadão teve vinculadas seis práticas organizacionais. Entretanto algumas delas não parecem suscitar efeitos benéficos para a organização, em termos práticos. Como a organização não tem capacidade de produzir receita, o período de renovação contratual, onde há riscos de ficar até quatro meses sem receber verbas, coloca a ONG em crise, literalmente, todos os anos. Poder-se-ia se dizer que, na perspectiva de Certeau (1984), as estratégias do grupo de balé, ao serem incorporadas pela ONG Corpo Cidadão, se transformam em táticas e com baixa eficiência.

Quanto ao conceito apresentado de estratégia, ele é mais que um esforço de escolha e sintetização de práticas observadas em um período de um ano acompanhando o Grupo Corpo. Nele também se sintetizam nove meses de produção de Grounded Theory, em um esforço analítico com codificações sucessivas e recodificações provocadas por reuniões de validação de interpretações junto aos gestores do Grupo Corpo. 
O estudo permitiu concluir que a observação, análise e integração das práticas é um caminho para identificar estratégias consolidadas em uma organização. Todavia nosso estudo tem limitações definidas pelo próprio objetivo de construção conceitual do que é estratégia para este grupo específico. A discussão de estratégia desenvolvida não permite nenhum tipo de generalização ou extensão de campo. O conceito desenvolvido explica como se dá a estratégia na prática da Cia. de Dança Grupo Corpo. Uma evolução desse trabalho e do conceito apresentado só será possível mediante outros estudos no mesmo setor. Consideramos que um esforço qualitativo múltiplo, organizado por um grupo de pesquisadores junto a um setor, teria mais possibilidades de produzir uma teoria formal de estratégia para este setor em estudo.

Os caminhos teórico-metodologicos escolhidos para construir o processo de identificar (a) Quem é o estrategista? (b) Que faz o estrategista? (c) Quais as práticas que efetivamente contribuem para o propósito estratégico da organização? Essas perguntas não são costumeiras de estratégia. Acreditamos que no apresentar destes caminhos estamos contribuindo, enquanto referência, para os estudos de administração que se proponham estudar as estratégias como prática no cotidiano das organizações, especialmente para aqueles que desejem somar no estudo de organizações do setor de cultura. O maior estímulo a novas pesquisas que este trabalho pode representar é a possibilidade de se tornar a mola propulsora, nas palavras de Strauss e Corbin (1998), de novas teorias substantivas mais robustas ou até mesmo de teorias formais no campo da estratégia como prática. Ficam, entretanto, algumas indagações que podem consubstanciar futuras investigações: Como ocorre o processo de reprodução de práticas dentro de organizações do mesmo setor? Em que circunstâncias, essa reprodução pode ser benéfica para a organização e em que condições ela pode não sê-lo? Que conceito de prática seria suficiente para identificar as práticas estratégicas?

\section{Artigo recebido em 20.09.2010. Aprovado em 01.08.2011.}

\section{Agradecimento}

A autora Valéria da Glória Pereira Brito agradece o apoio financeiro recebido da FAPEMIG por meio de sua bolsa de doutorado durante de desenvolvimento deste artigo.

\section{Notas}

${ }^{1}$ Alguns autores nacionais como Santos, L. L. S., Sette, R. S., \& Tureta, C. A. (2006, setembro). A estratégia como uma
prática social: em busca do que seja "fazer estratégia”. Anais do Encontro Nacional da Associação Nacional de Pós-
Graduação e Pesquisa em Administração, Salvador, BA, Brasil, 30, Tureta, C., Rosa, A. R., \& Santos, L. L. S. (2006,
setembro). Estratégia como prática social e actor-network theory: uma possível conversação para o estudo da estratégia.
Anais do Encontro Nacional da Associação Nacional de Pós-Graduação e Pesquisa em Administração, Salvador, BA,
Brasil, 30, Crubellate, J. M., Grave, P. S., \& Gimenez, F. A. P. (2005, setembro). Estratégia como configuração: uma versão
construtivista da estratégia em organizações. Anais do Encontro Nacional da Associação Nacional de Pós-Graduação e
Pesquisa em Administração, Brasília, DF, Brasil, 29, entre outros, adotam o neologismo "estrategizar” para se referir ao novo
verbo cunhado por Whittington (1996, p. 732).
${ }^{2}$ Aqui, de novo, observa-se uma proximidade da Análise Dimensional, proposta por Schatzman, com a Grounded Theory
construtivista de Kathy Charmaz.
${ }^{3}$ Clarke (2005, p. 45$)$ entende que os mundos sociais são “definidos como grupos com comprometimentos compartilhados
para certas atividades: compartilham recursos de diversas espécies para atingir seus objetivos e construir ideologias
compartilhadas sobre como agir em seus negócios e atividades”.
${ }^{4}$ Por elementos não humanos Clarke (2005) refere-se a todas as coisas não humanas, inanimadas e animadas, que também
constituem a situação social em que vivemos: algumas são produtos da ação humana e outras são produtos da natureza.
${ }^{5}$ Efeito borboleta é um termo base na teoria do caos, Proposto em 1963 pelo matemático Edward Lorenz, analisa, via
modelos matemáticos, que uma pequena variação em determinado ponto de um sistema dinâmico pode ter consequências de 
proporções inimagináveis. "O bater de asas de uma borboleta em Tóquio pode provocar um furacão em Nova Iorque" (Wikipedia. (n.d.). Teoria do caos. Recuperado em 26 fevereiro, 2011, de http://pt.wikipedia.org/wiki/Teoria_do_caos).

\section{Referências}

Agar, M. (1980). The professional stranger. Orlando: Academic Press.

Aquino, M. A. de (2001). Configurações etnográficas: demarcando um território de pesquisa. Revista Informação e Sociedade, 11(1), 1-24.

Ansoff, I. H. (1965). Corporate strategy: business policy for growth and expansion. New York: McGraw-Hill.

Balogun, J., Huff, A. S., \& Johnson, P. (2003). Three responses to the methodological challenges of studying strategizing. Journal of Management Studies, 40(1), 197-224. doi: 10.1111/14676486.t01-1-00009

Becker, H. S. (1986). Doing things together. Evanston: Northwestern University Press.

Bogéa, I. (n.d.). Histórico. Recuperado em 15 fevereiro, 2011, de http://www.grupocorpo.com.br/pt/historico.php

Cançado, M. (1994). Um estudo da pesquisa etnográfica em sala de aula. Trabalhos de linguística aplicada, (23), 55-69.

Certeau, M. (1984). A invenção do cotidiano. Petrópolis: Vozes.

Chandler, A. D. (1962). Strategy and structure: chapters in the history of American industrial enterprise. Cambridge, MA: MIT Press.

Charaudeau, P., \& Maingueneau, D. (2004). Dicionário de análise do discurso. São Paulo: Contexto.

Charmaz, K. (2000). Grounded theory: objectivist and constructivist methods. In N. K. Denzin \& Y. S. Lincoln (Eds.), Handbook of qualitative research (pp. 509-535). Thousand Oaks: Sage Publications.

Charmaz, K. (2005). Grounded theory in the 21st century applications for advancing social justice issues. In N. K. Denzin \& Y. S. Lincoln (Eds.), The SAGE handbook of qualitative research (pp. 507-535). Thousand Oaks: Sage Publications.

Clarke, A. E. (1991). Social worlds/arenas theory as organizational theory. In D. Maines (Ed.), Social organization and socials process: essays in honor of Anselm Strauss (pp. 119-158). Hawthorne: Aldine de Gruyter.

Clarke, A. E. (2003). Situational analysis: grounded theory mapping after the postmodern turn. Symbolic Interaction, 26(4), 553-576. doi: 10.1525/si.2003.26.4.553

Clarke, A. E. (2005). Situational analysis- grounded theory after the postmodern turn. Thousand Oaks: Sage Publications.

Fetterman, D. M. (1998). Ethography-step by step. Thousand Oaks: Sage Publications.

Glaser, B. G. (1992). Emergence vs. forcing: basics of grounded theory analysis. Mill Valley: Sociology Press.

Glaser, B. G. (1998). Doing grounded theory: issues and discussions. Mill Valley: Sociology Press. 
Glaser, B. G., \& Strauss, A. L. (1967). The discovery of grounded theory: strategies for qualitative research. New York: Aldine de Gruyter.

Jarzabkowski, P. (2003). Strategic practices: an activity theory perspective on continuity and change. Journal of Management Studies, 40(1), 23-55. doi: 10.1111/1467-6486.t01-1-00003

Jarzabkowski, P. (2005). Strategy as practice: an activity-based approach. London: Sage Publications.

Jarzabkowski, P., Balogun, J., \& Seidl, D. (2006, July). Five key questions and a conceptual framework for strategy-as-practice research. Anais of the EURAM Conference, Oslo, 6.

Jarzabkowski, P., Balogun, J., \& Seidl, D. (2007). Strategizing: the challenges of a practice. Human Relations, 60(1), 5-27. doi: 10.1177/0018726707075703

Jarzabkowski, P., \& Wilson, D. C. (2002). Top teams and strategy in a UK university. Journal of Management Studies, 39(3), 357-383. doi: 10.1111/1467-6486.00296

Johnson, G., Melin, L., \& Whittington, R. (2003). Micro strategy and strategizing: towards an activitybased view. Journal of Management Studies, 40(1), 3-22. doi: 10.1111/1467-6486.t01-2-00002

Katz, H. (2000). Os primeiros 25 anos deste corpo. Estudos avançados, 14(40), 311-332. doi: 10.1590/S0103-40142000000300023

Minayo, M. C. S. de, Deslandes, S. F., Cruz-Neto, O., \& Gomes, R. (1996). Pesquisa social: teoria, metodo e criatividade (6a ed.). Petropolis: Vozes.

Mintzberg, H. (1978). Patterns in strategy formation. Management Science, 24(9), 934-948. doi: 10.1287/mnsc.24.9.934

Mora, J. (2000). Dicionário de filosofia. São Paulo: Edições Loyola.

Neves, V. F. A. (2006). Pesquisa-ação e etnografia: caminhos cruzados. Pesquisas e Práticas Psicossociais, 1(1), 1-17.

Pettigrew, A. M. (1977). Strategy formulation as a political process. International Studies of Management \& Organization, 7(2), 78-87.

Pettigrew, A. M. (1987). Context and action in the transformation of the firm. Journal of Management Studies, 24(6), 649-670. doi: 10.1111/j.1467-6486.1987.tb00467.x

Porta, P. (2008, abril, 1). Economia da cultura: um setor estratégico para o país. Ministério da Cultura, Portal da Cultura. Recuperado em 11 novembro, 2008, de http://www.cultura.gov.br/site/2008/04/01/economia-da-cultura-um-setor-estrategico-para-opais/

Porter, M. E. (1989). Vantagem competitiva (22a ed.). Rio de Janeiro: Campus.

Porter, M. E. (1991). Estratégia competitiva: técnicas para analise de indústrias e da concorrência (5a ed.). Rio de Janeiro: Campus.

Reckwitz, A. (2002). Toward a theory of social practices: a development in culturalist theorizing. Europeand Journal of Social Theory, 5(2), 243-263. doi: 10.1177/13684310222225432

Samra-Fredericks, D. (2000). Doing 'boards-in-action'research - an Ethnographic approach for the captures and analysis of directors'and senior managers'interactive routines. Corporate Governance, 8(3), 244-257. doi: 10.1111/1467-8683.00202 
Samra-Fredericks, D. (2003). Strategizing as lived experience and strategists' everyday efforts to shape strategic direction. Journal of Management Studies, 40(1), 141-174. doi: 10.1111/14676486.t01-1-00007

Strauss, A. (1978). A social worlds perspective. In N. K. Dwnzin (Ed.), Symbolic interaction (pp. 119128). Greenwich: AL PRESS.

Strauss, A., \& Corbin, J. (1998). Basics of qualitative research: techniques and procedures for developing grounded theory. Thousand Oaks: SAGE Publications.

Tuckermann, H., Von Arx, W., \& Ruegg-Sturm, J. (2006, maio). How organizational practice act as a strategy generating principle- an empirical case from a University Hospital. Anais do European Academy of Management Conference, Oslo, Noruega, 22.

Vilela, S. (1980). Último trem: palco e bastidores (Entrevista com Oscar Araiz). Revista Pampulha, ano 2 (3), 36-41.

Walter, S. A., \& Augusto, P. O. M. (2009, novembro). Prática estratégica e strategizing: mapeamento dos delineamentos metodológicos empregados em estratégia como prática. Anais do Encontro de Ensino e Pesquisa em Administração e Contabilidade, Curitiba, Paraná, Brasil, 2.

Whittington, R. (1996). Strategy as practice. Long Range Planning, 29(5), 731-735. doi: 10.1016/0024-6301(96)00068-4

Whittington, R. (2002a). O que é estratégia. São Paulo: Pioneira Thomson Learning.

Whittington, R. (2002b). Practice perspectives on strategy: unifying and developing a field. Proceedings of the Annual Meeting of Academy of Management, Denver, CO, USA.

Wilson, D. C., \& Jarzabkowski, P. (2004). Pensando e agindo estrategicamente: novos desafios para a análise estratégica. Revista de Administração de Empresas, 44(4), 11-20.

Wisnik, J. M. (2000). O interesse pela dança foi despertado em mim por eles. Estudos Avançados, 14(40), 311-328. doi: 10.1590/S0103-40142000000300024 